\section{Yüksek İrtifa Merkezlerinin Yönetim Organizasyon Boyutları İle İncelenmesi: Davraz'a Yeni Model Öngörüsü ${ }^{1}$}

Analysis of High Altitude Centers with Organizational: Dimensions: New Model Forecast for Davraz
Strategic Public Management Journal Volume 4, Issue 8, pp. 17-34 December 2018 DOI: $10.25069 /$ spmj.475004 Received: 26.10.2018 Accepted: 06.12.2018 (C) The Author(s) 2018 For reprints and permissions: http://dergipark.gov.tr/spmj

\author{
Ahmet Hayrettin TUNCAY ${ }^{2}$ \\ Fatih KILINÇ ${ }^{3}$
}

$\ddot{O} z$

Spor, toplumların gücünü gösteren bir unsur olduğu için turizm sektöründe hem profesyonel hem de rekreasyon aktiviteleri açısından son yıllarda önem kazanmıştır. Bunun sonucunda yüksek irtifa merkezleri profesyonel ve rekreasyon boyutu ile hem turizm ekonomisini oluşturmuş, hem de tercih edilen alanlardan olmaya başlamuştır. Araştırmanın amacı, Davraz'da kurulması muhtemel olan yüksek irtifa kamp merkezinin nasıl bir tesis alt yapısına ve nasıl bir yönetim organizasyon yapısına sahip olması gerektiğini ortaya koymaktır. Araştırmada mevcut uluslararası ve ulusal çaptaki yüksek irtifa kamp merkezleri yönetim ve organizasyon boyutları ile literatür destekli incelenmiştir. Araştırmada, Avusturya Mölltaler, Kayseri Erciyes ve Erzurum Palandöken Kayak Merkezlerinde toplam 161 kişiye yüz yüze anket yapılmıştır. Araştırmada keşifsel araştırma modeli kullanılmıştır. Araştırmada Davraz'ın biyoiklimsel konfor düzeyinin yüksek olduğu, hem yükselti hem de eğim antremanları için mükemmel bir konuma sahi olduğu bulgularına ulaşılmıştır. Uluslararası ve ulusal yüksek irtifa merkezlerinin incelenmesi sonucu Davraz'a kurulacak olan yüksek irtifa merkezi tesislerinin kaliteli olması, tüm spor branşlarına cevap verebilecek nitelikte olması, saha, salon, pist, havuz, test, antrenman, beslenme, masaj, sakatlık tedavisi, güvenlik gibi temel ihtiyaçları bütünsel olarak karşılayabilir olması gerektiği sonucuna ulaşılmıştır.

Anahtar Kelimeler: Yüksek Irtifa, Spor Turizmi, Tesis.

\begin{abstract}
As sports is a factor that shows the power of societies, it has gained importance in the recent years in terms of both professional and recreational activities in the tourism sector. As a result of this, high altitude centers have established both the tourism economy and the tourism sector with their professional and recreation dimension. The aim of the study is to reveal how a high-altitude camp center, which is likely to be established in Davraz, should have a facility infrastructure and a management organizational structure. In this research, high-altitude

${ }^{1} \mathrm{Bu}$ çalışma Ahmet Hayrettin TUNCAY'ın "Uluslararası ve Ulusal Yüksek İrtifa ve Kamp Merkezlerinin Spor Turizminde Yönetim ve Organizasyon Boyutları ile İncelenmesi (Davraz’a Yeni Model Öngörüsü)” başlıklı doktora tezinden üretilmiştir.

${ }^{2}$ Dr., Süleyman Demirel Üniversitesi Rektörlüğü, Öğrenci İşleri Daire Başkanlı̆̆ı, hayrettintuncay@sdu.edu.tr

${ }^{3}$ Prof. Dr., Akdeniz Üniversitesi, Spor Bilimleri Fakültesi, fatihkilinc@akdeniz.edu.tr
\end{abstract}


camp centers in international and national scale were examined with the support of literature and organization dimensions and literature. A total of 161 people were interviewed face-to-face in the study at the Mölltaler, Kayseri Erciyes and Erzurum Palandöken Ski Centers. In the research, the exploratory research model was used. In the research, it was found that Davraz's bioclimatic comfort level was high and it was found to be in a perfect position for both elevation and inclination training. Quality of high-altitude facilities to be established in Davraz as a result of examination of international and national high altitude centers, being able to respond to all sports branches, field, hall, runway, pool, test, training, nutrition, massage, disability treatment, safety it is concluded that the needs must be holistic.

Key words: High Altitude, Sports Tourism, Facility.

\section{GíRiş}

Yüksek irtifa antremanı yükseklik hipoksiyasının organizmada meydana getirdiği avantaj sağlayıcı fizyolojik uyumlardan sportif performans elde edilmesi olarak tanımlanmaktadır. Bu alanda ilk ciddi çalışmalar 1968 Meksika Olimpiyatları nedeni ile ele alınmıştır. Meksika Olimpiyatları'ndan sonra yüksek irtifada yaşayan atletlerin özellikle dayanıklılık sporlarında daha üstün performans göstermeleri, bilim adamlarını yüksek irtifa antrenmanı ile performans arasındaki ilişkiyi araştırmaya yöneltmiştir. Bu alanda yapılan çalışmalar yüksek irtifanın sağladığı oksijeni az alanlarda yapılan hipoksik antremanların sporcularda performans ve dayanıklılığ 1 artırıcı yönde olumlu etki yaptığını ortaya koymaktadır.

Gelişmiş ülkelerde olduğu gibi, ülkemizde de sporun yaygınlaşması ve elit yarışmacı sporcuların yetiştirilmesi büyük önem arz etmektedir. Bu sürecin başarılı yönetilmesi, iyi bir tesis alt yapısının geliştirilmesi ile mümkündür.

Spor-kamp turizmi için iklim özelliklerinin önemli bir yeri bulunmaktadır. Aşırı sıcak ve soğuk hava şartlarının, sporcu sağlığını olumsuz etkilediği ve uygun olmadığı bilinmekte olup, ayrıca sürekli yağışlar ve yüksek nem oranları da kamp için pek tercih edilmemektedir.

Dünyada olduğu gibi ülkemizde de spor turizmi faaliyetleri hızla gelişmekte, özellikle alternatif turizm veya özel ilgi turizminin ilgi alanlarına giren bu turizm çeşidi genel turizmin içinde kendisini daha fazla hissetmekte, turizm gelirlerinden daha fazla pay almaktadır. Ülkemizin gerek zengin doğal kaynakları, gerekse pek çok farklı spor turizmi çeşidine, hatta aynı gün içerisinde farklı türden aktivitelere katılmayı olanak sağlayan coğrafi konumu göze alındığında bu mevcut potansiyelin yeterince değerlendirilmediği görülmektedir.

Ülkemizde yüksek irtifa kamp merkezlerinin sayısının artması ile sporcularımızın performansının artırılmasının yanı sıra, yeterli tanıtım ve amaca uygun yatırımların yapılması halinde yurt dışından da takımların antreman için ülkemizdeki yüksek irtifa merkezlerini tercih etmesi sonucu ciddi bir döviz girdisi sağlanması hedeflenmektedir.

\section{SPOR TURIZMII KAVRAMI}

Turizm, genel olarak devamlı yaşanan yer dışında tüketici olarak, tatil-dinlenme-eğlenme gibi ihtiyaçların giderilmesi amacı ile yapılan seyahat ve geçici konaklama hareketidir. (Bayer, 1992:3).

Turizmin sadece ekonomik yönüyle ilgili tartışmaları başlatan kişi 1910 yılında Avusturyalı ekonomist HermannVon Schullar olmuştur. Schullar turizmi; başka bir ülkeden, şehir veya bölgeden yabancıların gelmesi 
ve geçici süre kalmalarıyla ortaya çıkan hareketin ekonomik yönünü ilgilendiren faaliyetlerin tümü olarak nitelendirerek, konuyu sosyo-kültürel yönden ele almaktadır. (Kozak N., Kozak M.A. ve Kozak M.,2012:1)

Turizm faaliyetini tanımlarken dikkat edilecek ilk unsur hareket ve geri dönüş olayıdır. Turizm faaliyetlerinde devamlı kalış şekline dönüşmeyen bir gezme, gidilen yerde geçici bir kalış ve sonra ikamet yerine dönüş söz konusudur. Turizmde hareket, seyahat, gezme kavramı vardır. Gezmek, seyahat etmek öncelikle para harcamayı gerektirir. Gidilen yerde geçici de olsa konaklamayı gerektirir. Turist, görmek istediği yerlere giderken araca binecek, yemek yiyecek, eğlence yerine gidecek, tarihi ve turistik yerleri gezecek, hediyelik eşya alacak ve bütün bu faaliyetler için de harcama yapacak ve para ödeyecektir. (Sezgin, 2001:13)

Turizm faaliyetini tanımlarken dikkat edilecek diğer bir unsur ise faaliyetlerin bir hizmet ve tüketim niteliği taşımasıdır. Turistin tüketici olarak bulunduğu yer, çalıştığı ve sürekli olarak yaşadığı yerden farklıdır. Yani turist genel anlamıyla zevk için gittiği yerde geçici olarak kalacak ve belirli bir süre sonra ikametgahına geri dönecektir. O halde, turizmle ilgili bir tanımlanma yaparken aşağıdaki unsurları dikkate almak gerekir: (Sezgin, 2001:13-14)

-Kişilerin sürekli olarak oturdukları yerin dışında olması,

-Seyahat nedeninin geçici olması,

-Seyahat nedeninin bir yerde çalışmak, iş yapmak amacını gütmemesi,

-Gittikleri yerde tüketici durumunda olmas1,

-Geçici konaklamadan sonra sürekli ikametgahlarına dönülmesi.

\section{YÜKSEK İRTIFA MERKEZLERİ}

\subsection{Yüksek İrtifa Merkezlerinin Performans Açısından Önemi}

Yapılan çalışmalar yüksek irtifanın sağladığı oksijeni az alanlarda yapılan hipoksik egzersizlerin sporcularda performans ve dayanıklılığı artırıcı yönde etki yaptığını ortaya koymaktadır. İnsan vücudu; irtifası yüksek alanlarda bu yüksekliğe uyum sağlamak adına hemoglobinin artması, alyuvarların çoğalması ve yüksek solunum hızı gibi göstergeleri içeren bir dizi değişikliğe gitmektedir. Alyuvar üretiminin artması ile yüksek irtifada vücut oksijen taşıyabilme kapasitesini artırmaktadır. Uygun yükseklikte ve sürede yapılan yüksek irtifa antrenmanının ardından sporcuda oksijen kullanma kapasitesi ve hemoglobin seviyesi artarak kas dokusunu oksijenli ve oksijensiz ortamlarda dayanıklı hale getirmektedir. $\mathrm{Bu}$ antrenman sporcunun daha düşük rakımlarda performansını ve dayanıklılığını artırmaktadır. Her tür spor branşından antrenörler sporcularından bekledikleri yüksek dayanıklılık ve performansı özellikle sezon başlarında yaptıkları yüksek irtifa hazırlık kamplarında elde etmektedirler. (http://erzurumdayatirim.kudaka.org.tr, 2017)

Atmosfer basıncının azalmasına bağlı olarak gerek solunan havada, gerekse alveollerde parsiyel oksijen basıncı ( p 02 ) düşer ve kanın 02 ile satürasyonu bozularak "hipoksik hipoksia" durumu ortaya çıar. Hipoksinin organizmaya etkileri; yükseklik düzeyi, yüksekliğe çıkış sürati, yükseklikte kalış süresi, ortam 1sısı, fiziksel aktivite derecesi ve bireysel faktörlere bağlı olarak değişir. Hipoksinin (normobarik veya hipobarik) akut başlangıcında 1-2 saat içerisinde dolaşımdaki eritropoetin (EPO) seviyesi anlamlı şekilde yükselmeye başlar. Hipoksinin derecesine bağlı olarak zaman içerisinde maksimum düzeyine ulaşır. Bu nedenle dağcılar genellikle yüksek irtifa tırmanışlarında zirveye ulaşmak için oldukça uzun süreye ihtiyaç duyarlar ve bu sayede hipoksinin dereceli yükselişine karşı dayanırlar. İrtifa artışına bağlı yükseklik hipoksisinde ilk birkaç saatte başlayan ve birkaç gün devam edebilen solunum sisteminde hiperventilasyon görülür ve bir hafta sonunda bu solunumsal değişiklik stabil hale gelir. Oluşan hiperventilasyon sonucuda karbondioksit azalmasına bağlı olarak kan pH'sı 
alkali tarafa kayar. Yüksekliğe adaptasyonun en önemli etkisi oksijen taşıma kapasitesinin artmasıdır. Başlangıçta plazma volümü azalmasına bağlı meydana gelen hemokonsantrasyon sonucu olarak eritrosit ve hemoglobin miktarında hızlı bir artış görülür. Bu mekanizma yüksekliğe çıkışların ilk 48 saati içinde kendini gösterir. Kırmızı kan hücreleri tarafından oksijen taşınması eritropoiesis ve $\mathrm{Hb}$ - 02 afinitesi ile regüle edilir. Oksijen taşıma kapasitesi; hematokrit, eritrosit sayımı ya da dolanımda bulunan kırmızı kan hücresi kütlesi ile karakterize edilir. Yüksek irtifanın dayanıklılık ve performans üzerine etkilerini araştıran çalışmalardan geçmişte 5000 feet'in (1524 m) üzerinde her 1000 feet (304.8 m) artışta \% 3-3,5 civarında maksimal oksijen tüketiminde dolayısıyla dayanıklılık kapasitesinde azalma olduğu biliniyordu. Ancak son çalışmalarda deniz seviyesinden 5000 feet'e kadar olan yükseltilerde de bu azalmanın başlayabileceği gösterilmiştir. Oldukça yüksek irtifada (25000 feet (7620 m) civarında) max V Oksijen ve dolayısıyla iş performans1 \%60 ya da daha fazla azalma gösterir. (Güzel ve Şenel, 2001:30-31)

\section{Şekil 1. Hipoksianın İnsan Vücuduna Etkileri}

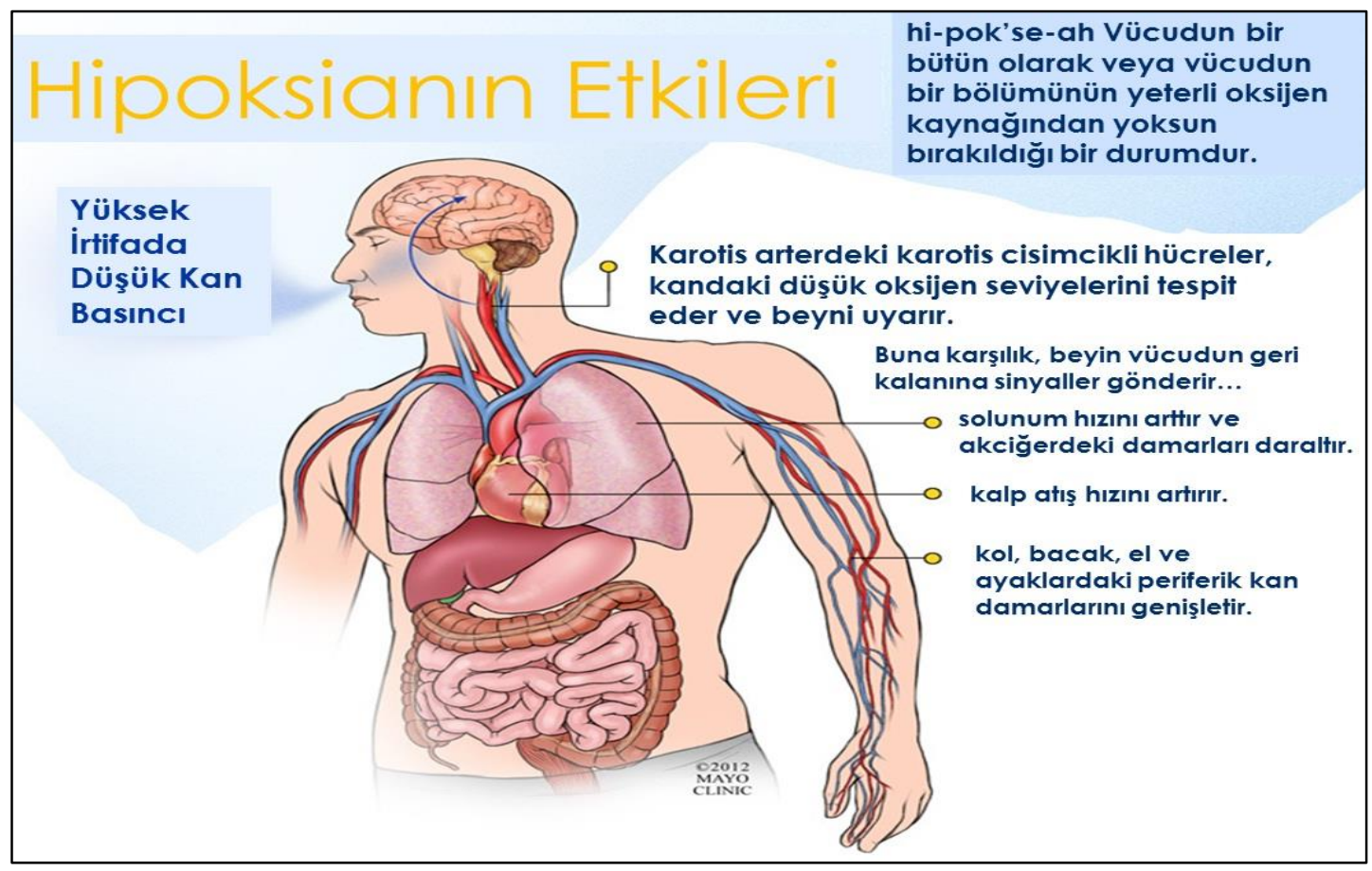

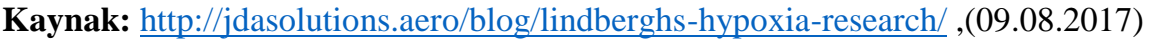

\subsection{Uluslararası Yüksek İrtifa Merkezleri}

\subsection{1. İsviçre St Moritz}

St Moritz, deniz seviyesinden 1.856 metre yükseklikte İsviçre Yüksek İrtifa Olimpiyat Eğitim Merkezi'nin evidir. Dünya ve Olimpiyat Oyunlarına hazırlanan uluslararası ekiplerden eğlence amaçlı sporculara kadar her seviyedeki sporcu Engadin Vadisi'ndeki bu bölgeye yönelmektedir. İlk yüksek rakımlı eğitim tesisleri, 1968 Meksika Olimpiyat Oyunlarına hazırlanan sporcular için St Moritz'de inşa edilmiştir. St Moritz'de yılda ortalama 322 gün güneş 1şı̆̆ alan tipik bir Alp iklimi hüküm sürmektedir(www.whichtrainingcamp.com, 07.01.2018). 
Tesis, beş kayak bölgesini (Lagalb, Diavolezza, Corvatsch, Furtschellas ve Corviglia) birleştirir ve bunların 220 kilometrelik arazisine 56 asansörle hizmet vermektedir. Son zamanlarda tesiste, eski t-barlar yerini yüksek hızlı telesiyejlerle değiştirmiştir, böylece yıldızların yukarı yönlü kapasitesi artırılmıştır. Engadin Kayak Maratonu'na ev sahipliği yapan İskandinav pistleri oldukça popülerdir ve beldenin etrafinda 115 mil uzunluğunda kros parkurları bulunmaktadır(www.whichtrainingcamp.com, 07.01.2018).

1 Ocak 2014'te İsviçre'de türünün en eski ve en ünlü turizm kurulu olan St. Moritz Turist Kurulu, operasyonlarını ve çalışanlarını St. Moritz belediyesine teslim etmiştir. St. Moritz Belediyesi daha sonra sportif etkinlikler ve altyapı olmak üzere iki bölüme ayrılan St. Moritz Turizm departmanını kurmuştur. 2008 yılında tüm pazarlama faaliyetlerinin sorumluluğunu üstlenen Engadin St. Moritz Turizm Organizasyonu'nun kuruluşundan bu yana, St. Moritz, faaliyetlerini markasının bakımı ve bölgenin turistik mekanlarının koordinasyonu ve temsili konusunda yoğunlaştırmıştır. St. Moritz Turizm, Engadin St. Moritz Turizm Organizasyonu ile yakın işbirliği içinde çalışmaktadır. St. Moritz Sportif Etkinlikler bölümü, St. Moritz'deki spor, etkinlik ve kültür programlarından sorumludur. Bu programın amacı, mevcut konukları korumak ve yeni konuklar çekmektir. St. Sportif Etkinlikler ayrıca, irtifa eğitimi almak isteyen sporcular için akreditasyon sağlamakta, St. Moritz'in dijital iletişimini yönetmekte ve çeşitli baskı materyallerini yayınlamaktadır. Altyapı departmanı, yeni su sporları merkezi Ovaverva ve St. Moritz'in diğer spor tesislerini işletmekten sorumludur. Bunlar arasında St. Moritz-Celerina Olimpik bob koşusu, Cresta Run, Ludains buz pateni pisti ve irtifa eğitim merkezi bulunmaktadır. (www.stmoritz.ch/en/service/about-us/, 13.02.2018)

\subsubsection{Fransa Font Romeu}

Deniz seviyesinden 1.850 metre yükseklikte yer alan Font Romeu Ulusal Yüksek İrtifa Merkezi, atletlerin Meksika Olimpiyat Oyunlarına hazırlanmaları amacıyla 1967'de açılmıştır. Font-Romeu, Fransa / İspanya sınırına yaklaşık $10 \mathrm{~km}$ uzaklıktaki Pireneler'de yer almaktadır. Perpignan'a yaklaşık $75 \mathrm{~km}$ uzaklıktadır (www.whichtrainingcamp.com, 05.01.2018).

Yılda en az 3000 saat güneş gören, Katalan Pireneleri'ndeki küçük bölge Font-Romeu-Odeillo-Via, Fransa'nın en güneşli şehridir. Ancak sadece güneşe hasret olanlar değil, aynı zamanda birbirinden çeşitli pist ve parkur olanaklarının kıymetini bilen kış sporcuları da burayı tercih etmektedir. Bu sempatik kış sporları mekanı 1920'de bölgesel milli park Pyrénées Catalanes'ın tam ortasında kurulmuş olup, zamanla özellikle kuzey disiplinli sporlara yeni başlayan sporcular için bir cazibe noktası haline gelmiştir. Öyle ki Font-Romeu'nun kayak bölgesi ve komşu istasyon Pyrénées, 43 adet alp disiplinli pistin yanı sıra toplam 111 kilometrelik kayak yürüyüş parkuru sağlamaktadır. Bu durum, Font-Romeu'yu Pireneler'in, yalnızca en büyük parkur alanı yapmakla kalmayıp, bölgeye en yüksek parkur ağı olma özelliğini de kazandırmaktadır(https://tr.skifrance.com, 08.01.2018).

Kamp merkezi, Mo Farah, Galen Rupp, Dathan Ritzenhein gibi dünya çapında sporculara ve programlarına rakım kros eğitim eklemek isteyen diğer uluslararası spor federasyonlarından ekiplere ev sahipliği yapmaktadır. 26 ulustan 30 atlet Londra 2012 Olimpiyat Oyunları'na Fonta-Romeu'da hazırlanmıştır. Bu 30 sporcudan 20'si olimpiyatı tamamlamış olup, 11'i ise madalya kazanmıştır(www.whichtrainingcamp.com, 05.01.2018).

\subsubsection{Kenya Iten}


Iten Yüksek İrtifa Eğitim Merkezi 1999 yılında Lornah Kiplagat tarafından kurulmuştur. Lornah Kiplagat 4 kez dünya şampiyonu olmuş bir atlettir. Iten, atletizm için Dünya'nın başkentidir, Iten'de 800'ün üzerinde sporcu eğitim almıştır ve bunların arasında dünya şampiyonları, olimpiyat şampiyonları ve dünya rekoru sahipleri vardir(http://hatc-iten.com, 12.02.2018).

Eğitim programında kişiye özel tavsiyelerde bulunulmaktadır ve bir grup Kenyalı sporcuyla tanıştırarak antrenmanlardan en iyi şekilde yararlanılması için yardımcı olunmaktadır. Ziyaretçiler kendi programını takip edebildikleri gibi, kendileri için bir program tasarlanmasını isteyebilmektedirler(http://www.runninginiten.com, 20.02.2018).

Kenya Deneyimi, seçkin koşucular için Iten'de çalıştırılan koçlu kamplar sunan ilk şirkettir. Elit koşucuların yanı sıra amatör koşucular için de uzman rehberliği ve koçluk ile desteklenen şekilde tasarlanmıştır. Iten bölgesinde ve Kenyalı koşu topluluğunda geniş bilgi ve temaslarla yerel personel çalıştırılmaktadır. Tüm çalışanlar Iten'de yaşamaktadır. Kamplar, pozitif bir grup ortamı yaratmak için yeterince büyüktür, ancak her koşucunun koçluk personelinden ve tur rehberlerinden kişisel ilgi görmesini sağlayacak kadar küçüktür(http://www.traininkenya.com/, 25.02.2018).

\subsubsection{Bolivya La Paz}

La Paz, Titicaca Gölü'nün 68 km güneybatısındaki Bolivya'nın batısında, Choqueyapu Nehri'nin oluşturduğu bir kanyonda yer almaktadır. Altiplano'nun yüksek dağlarıyla çevrili çanak benzeri bir lokasyonda bulunmaktadır. Illimani üçlü zirveleri her zaman karla kaplıdır ve şehrin birçok bölgesinden görülebilmektedir. Deniz seviyesinden yaklaşık 3650 metre yükseklikte bulunan La Paz, dünyanın en yüksek başkentidir. Yüksekliği nedeniyle, La Paz yağmurlu yazları ve kuru kışları ile sıra dışı subtropikal yayla iklimine sahiptir(https://en.wikipedia.org/wiki/La_Paz/, 25.02.2018).

Estadio Hernando Siles Stadyumu 1931 yılında açılmıştır ve 41143 koltuk kapasitesine sahiptir. Deniz seviyesinden 3637 metre yükseklikte, dünyanın en yüksek stadyumlarından biridir. Bolivya milli takımının evinde çok puan almasının en büyük sebebi budur. Ziyaretçi takımlar, maç öncesi yüksek irtifaya alışmak için yeterli zamana sahip değildir(https://slovenianstravel.com, 25.02.2018).

\subsubsection{Bulgaristan Belmeken}

Belmeken Spor Kompleksi deniz seviyesinden 2050 m yükseklikte, Rodop dağları ile Rila arasında, Sofya'ya $130 \mathrm{~km}$ uzaklıkta yer almaktadır. 1968 yılında inşa edilmiş olup, 2003 ile 2010 yılları arasında tamamen yenilenmiştir. Rila Milli Parkı ve Belmeken Barajı yakınında yer alır ve Rusya, Ukrayna, Almanya, Norveç, Japonya ve Avustralya başta olmak üzere dünyanın her yerinden popüler sporculara antreman hizmeti vermektedir (https://smartsport.com, 20.07.2018).

Belmeken Spor Kompleksi bireysel spor antrenmanları, her türlü sporda milli takımlar ve kulüp takımları için eğitim kampları, dă̆ bisikleti, oryantiring, kayak oryantiring, yürüyüş, konferanslar, seminerler, kurslar gibi kitlesel spor etkinlikleri için ideal tesis alt yapısına sahiptir(https://kittbg.com, 20.07.2018).

\subsection{Ulusal Yüksek İrtifa Merkezleri}

\subsubsection{Erzurum Palandöken}


2200-3176 metre yükseklik aralığında yer alan ve Erzurum kentinin güneyinde kuzeydoğu-güneybatı doğrultulu olarak uzanan Palandöken dağları, yaklaşık $70 \mathrm{~km}$. uzunluğunda, $25 \mathrm{~km}$. genişliğinde bir alanı kaplamaktadır. Kış sporları ve kış turizmi hareketleri bakımından Türkiye'nin birinci derecede önemli ve öncelikli alanları arasında yer alan Palandöken serbest kayak ve kış turizmi açısından uluslararası bir istasyon özelliğindedir. (Ülker, 1992:198)

Palandöken Kayak Merkezi'ndeki pistler dünyanın en uzun ve dik kayak pistleri arasındadır. Pistlerin toplam uzunluğu 28 km., en uzun pisti 12 km. dir. Kayak alanı 2200-3176 m. yükseklik kuşağı üzerinde yer almaktadır. Başlangıç yeriyle varış noktası arasındaki yükseklik farkı $1000 \mathrm{~m}$. dir. Slalom ve büyük slalom yarışmaları için Ejder ve Kapıkaya pistleri tescilli pistlerdir. Kayak Merkezi'nde 5 adet telesiyej (toplam 4500 kişi/saat kapasiteli), 1 adet teleski (300 kişi/saat kapasiteli), 2 adet baby lift (toplam 1800 kapasiteli), 1 adet gondol lift (1500 kişi/saat kapasiteli) hizmet vermektedir. Palandöken Kayak Merkezi'nde toplam 22 adet pist mevcut olup, bu pistlerden ikisi FIS tarafından 1967-83 tescil nosu ile olimpik pist olarak tescillenmiştir. (http://www.tkf.org.tr, 07.03.2018)

Erzurum Büyükşehir Belediyesi'nin sosyal tesislerinden biri olan Yüksek İrtifa Kamp Merkezi, Türkiye'nin en önemli kamp merkezlerinden biridir. Palandöken Dağı'nın eteklerinde 2 bin rakım üzerinde kurulan kamp merkezi, deniz seviyesinden yüksekteki özelliği ve havasıyla sporcuların güç ve enerjilerine dinamizm katan bir özelliğe sahiptir. (http://www.bberzurumspor.com, 09.03.2018)

PGI Management Projesi (Türkiye - Erzurum, Grand Erzurum Kayak Merkezi İşletilmesi ve Yönetimi) Türkiye'nin en ünlü iki kayak merkezi olan Palandöken ve Konaklı tesislerinin yönetimini ve Dağ Turizmini Geliştirme gibi tamamlayıcı işletme çalışmaları ile satış ve pazarlama faaliyetleri konusunda uzman danışmanlığı içermektedir. PGI, tesislerin denetimi, işe alım süreci, satın alma listelerinin ve kayıt defterlerinin hazırlanması hakkında danışmanlık da dahil olmak üzere kayak merkezi işletimi için gereken yönetim ve yardımdan sorumlu kuruluştur. Şirket ayrıca, her iki kayak tesisinin işletilmesi için bütçenin detaylandırılmasını kontrol etmekte olup, aynı zamanda PGI uzmanları, operasyon planlarının uygulanması, gerçekleştirilmesi ve işletme planlarının güncellenmesini sağlayan en modern çözümleri sağlamaktadırlar. PGI, aynı zamanda kayak-kar tesisleri işletmeciliğinde uzmanlaşmış bir danışman sıfatıyla, Dünya Üniversiteler Kış Oyunları (Erzurum Universiade 2011) için yapay kar üretme, kar temizleme, kar şekillendirme ve yarış pistleri yönetiminde teknik asistanlık hizmetleri de vermiştir. (http://www.pgimgmt.com, 08.05.2018)

\subsubsection{Kayseri Erciyes}

Türkiye'nin önemli dağcılık ve kış sporları merkezleri arasında yer alan Erciyes Dağı 3917m. Yükseklikte olup, Kayseri ovasının 1100m. güneyinde yükselir. Dağın batısında Sultan sazlığı, güneyinde ise Develi ovası yer alır. Çevre ovalara göre 2900metre daha yüksekte olan Erciyes dağı İç Anadolu bölgesinin en yüksek volkanik dağıdır. (Ülker, 1992:144)

Erciyes Kayak Merkezi'nde kayak yapılacak en uygun zaman Aralık ve Nisan aylarıdır. Kayak sezonu ise 15 Kasım'da başlayıp 1 Mayıs'da sona ermektedir. Kayak merkezinde bulunan pistlerin yüzde 75'lik bölümünde suni karlama sistemleri kurulmuştur. Kayak merkezinde; 935 metre uzunluğunda Kaniş (açık kabin oturaklı), 2173 metre uzunluğunda Kültepe (kapalı kabin oturakl1), 200 metre uzunluğunda Arlberg (Kapalı yürüyen bant sistemi), 1600 metre uzunluğunda Tekir Gondol, 1400 metre uzunluğunda Zümrüt 2 (açık kabin oturakl1), 200 metre uzunluğuna Hisarcık (kapalı yürüyen bant sistemi), 1853 metre uzunluğunda Keven (kapalı kabin oturakl1), 2736 metre uzunluğunda Divan (kapalı kabin oturaklı), 1613 metre uzunluğunda Ottoman (kapalı kabin oturakl1), 1434 Sırt (açık kabin oturakl1), 900 metre uzunluğunda Yalçın (açık kabin oturaklı), 1589 metre 
uzunluğunda Karakulak (açık kabin oturakl1), 725 metre uzunluğunda Kartın (açık kabin oturakl1), 2495 metre uzunluğunda Lifos Gondol, 2225 metre uzunluğunda Hitittepe (kapalı kabin oturakl1), 300 metre uzunluğunda Hacılar (kapalı yürüyen bant sistemi) bulunmaktadır. (https://gezilmesigerekenyerler.com, 06.04.2018)

Kayseri Büyükşehir Belediyesi'nin yapmış olduğu yatırımları yönetmek üzere kurulmuş olan ve Türkiye'nin ilk ve tek dağ yönetim şirketi olan Kayseri Erciyes A.Ş. ülkemizde kış turizmine öncülük etmektedir. Erciyes Dağı üzerinde bulunan teleferiklerin işletilmesi, kayak pistlerinin hazırlanması, güvenlik tedbirlerinin alınması, suni karlama sistemiyle kar üretilmesi gibi saha hizmetlerinin yanında yaz faaliyetleri ve sportif aktivitelerle alakalı bütün süreçler şirket tarafından yönetilmektedir. Erciyes Kayak Merkezi'nin global çapta tanıtım ve pazarlanması, yurtiçi ve yurtdışı fuarlar, seminerler, sunumlar yine şirket tarafindan yürütülmektedir. (http://www.kayserierciyes.com.tr, 01.06.2018)

\subsubsection{Kastamonu Ilgaz}

Orta Anadolu'dan Kuzey Anadolu'ya geçiş kuşağında yükselen Ilgaz Dağı volkanik kayaçlardan meydana gelmiştir. Türkiye'nin en uzun ve hareketli kırık hattı olan Kuzey Anadolu Fayı, Ilgaz Dağının güney eteklerinden geçmektedir. Ilgaz Dağının eteklerinden doruklarına doğru gelişen karaçam, kızılçam, köknar hakim ağaç türlerinden meydana gelen bitki örtüsü, zengin orman altı topluluğu ile desteklenmektedir. (Alışık A., 2010:150)

Ilgaz Dă̆ı'nın 1050-2000 m arasında yükseklikte bulunmaktadır. Ilgaz Dağı Milli Parkı sınırları içindedir. Kurulduğu açık alanın toplam uzunluğu takribi 1500 m, genişliği 100 m civarındadır. Çevresi köknar, çam ormanlı ile örtülüdür. Aynı zamanda piknik, avcılık, safari, yürüyüş gibi çok çeşitli turizm imkânları da bulunmaktadır. Kayak merkezinde 800 m ve 1500 m uzunluğunda iki adet kayak pisti bulunmaktadır. Gençlik ve Spor Genel Müdürlüğü ne ait 1 adet çift oturaklı telesiyej tesisi çalışmaktadır. Üst istasyonu $1995 \mathrm{~m}$, alt istasyonu1850 m. irtifadadır. Tesisin uzunluğu $693 \mathrm{~m}$, kapasitesi ise $688 \mathrm{kişi} \mathrm{/} \mathrm{saattir.} \mathrm{Ayrıca} 1$ adet teleksi tesisi mevcuttur Hat boyu 950 m, kapasitesi ise 800/1000 kişi saattir. Telesiyej alt istasyonu yakınında Köy Hizmetleri Genel Müdürlügüne ait 1 tesis ile 1 adet özel teşebbüs konaklama tesisi bulunmaktadır. Geçtiğimiz yıllarda yapımına başlanan özel teşebbüs tatil köyünün bir bölümü hizmete açılmıştır. Ayrıca Ankara Üniversitesine ait Ilgaz Tesislerinde resmi ve sivil ziyaretçilere hizmet vermektedir. Sağlık ihtiyaçları için, sezon sırasında ambulans ve sağlık ekibi görevlileri bulunmaktadır. Telefon ve GSM haberleşmesi kesintisiz sürmektedir. Kastamonu Ilgaz Kış Sporları Turizm Merkezi 2634 Sayılı Turizmi Teşvik Kanunu ve Bakanlar Kurulu Kararı ile Turizm Merkezi olarak ilan edilmiştir. (https://www.kulturportali.gov.tr, 26.04.2018)

\subsubsection{Bursa Uludağ}

Bursa şehrimizin güneybatısında yer alan, Fatintepe ve Kuşaklıkaya adlarındaki 2 tepe üzerinde kurulmuş olan Uludağ Kayak Merkezi, 11 bin 338 hektarlık alanı içeren milli park da dahil, Bursa şehir merkezine yarım saatlik mesafededir. 1961 yılında milli park ilan edilen ve Bursa şehir merkezine 36 kilometre mesafede yer alan Uludağ Kayak Merkezi, modernliği ve kalitesi ile Türkiye kış turizminin merkezi konumundadır. Otellerin bulunduğu 1800 metre rakım ile başlayan kayak merkezi, 2200 metre rakıma kadar çıkan kayak tesisleri ve 2543 metrede bulunan zirvesiyle hem ülkemizden hem de dünyanın birçok ülkesinden 12 ay boyunca yoğun ziyaretçi ağırlamaktadır. (http://www.uludaginfo.com, 29.04.2018)

Uludağ Kayak Merkezi'nde 11 adet ana pist yer almaktadır. Alpin usulü, snowboard, cross country, heli skiing stillerinde kayak yapılan pistlerle birlikte, hayli geniş ve bir o kadar da rahat olan arazinin her yerinde kayak 
yapılabilmektedir. 13 adet liftin, 7 adet telesiyej, 6 adet teleski, 7 adet $t$ barın, 24 saat açık olan acil yardım merkezi ve 1 adet mobil kliniğin yer aldığı Uludağ Kayak Merkezi’nde, en uzun pist 2.000 metre en uzun telesiyej ise 1700 metredir. Uludağ Kayak Merkezi'ndeki toplam pist uzunluğu $25 \mathrm{~km}$ dolaylarındadır. (http://www.tkf.org.tr, 29.04.2018)

I. Gelişim ( Oteller ) Bölgesinde özel sektöre ait 18 adet turizm tesisi; kamuya ait 12 adet tesis, II. Gelişim Bölgesinde ise; özel sektöre ait 4 adet turizm tesisi hizmet vermektedir. Ayrica Kirazliyayla'da kamuya ait 2 tesis bulunmaktadır. Oteller Bölgesinde kayak turizmine hizmet veren 22 adet mekanik tesis (teleski-telesiyej) mevcuttur. Teleski ve telesiyej hizmeti yap-işlet-devret modeli olarak Bursa Teleferik A.Ş. tarafindan verilmektedir. Milli Parkta bulunan turizm ve kamu tesisleri daha çok kış turizmine yönelik hizmet vermektedir. (http://bolge2.ormansu.gov.tr, 30.04.2018)

\subsubsection{Bolu Kartalkaya}

Türkiye'nin en gözde kayak merkezlerinden biri olan Kartalkaya Kayak ve Snowboard Merkezi Batı Karadeniz bölgesinde, Bolu ilinin güneydoğusunda, Köroğlu dağları üzerinde yer almaktadır. Kartalkaya Kayak Merkezi alp disiplini kayak ve tur kayağı için çok uygun koşullara sahiptir. Kartalkaya Kayak Merkezi’nin kayılabilen alanı 1850 - 2200 metre yükseklik kuşağı üzerinde bulunmaktadır. Bölge yarı 1lıman bir iklime sahip olup, Kartalkaya Kayak Merkezi ve çevresi çam ormanlarıyla kaplıdır. Hakim rüzgar yönü batı - kuzeybatıdır. Türkiye'de kayak denince akla ilk gelen yer olan Kartalkaya Kayak Merkezinde aralık ayı başlarından mart ayı sonlarına kadar kayak yapılabilmektedir. Kartalkaya Kayak Merkezi'nde 3 metreye kadar kar görülmektedir. (http://www.tkf.org.tr, 01.05.2018)

Kartalkaya Kayak Merkezi edilen Bolu - Köroğlu Dağı Turizm Alanı 1. Gelişim Bölgesi içinde yer alır. Bölgedeki 5 adet tesis, kış sezonu olan aralık - nisan ayları arasında toplam 1600 yatağıyla faaliyet yürütmektedir. Kartalkaya otelleri bünyesinde 2 ana kayak alanı içerisinde toplam 18 adet mekanik tesis ile çeşitli eğim ve zorluk derecelerinde toplam 25 adet pist vardır. Pistlerin toplam uzunluğu 40 kilometreyi bulmaktadır. Kartalkaya'da özel sektöre ait 5 adet konaklama tesisi mevcuttur. Oteller her türlü aktivite ve konfora sahiptir. Mekanik tesislerin toplam kapasitesi saatte 8000 kişidir. Tesislerde deneyimli kayak ve snowboard öğretmenleri eğitim vermektedir. Her otelin kendi bünyesinde ilkyardım ve sağlık hizmeti sunulmaktadırr. Tesislerden her türlü kayak malzemesi kiralanabilmekte olup Türkiye'nin Avrupa standartlarında en büyük snowparkları Kartalkaya'da bulunmaktadır. Alanda çeşitli zorluk derecelerinde 6 adet ana rampa-kicker line, mükemmel dizayn edilmiş bordercross, rail line ve rail-boxlar vardır. (https://www.kulturportali.gov.tr, 01.05.2018)

\subsubsection{Antalya Saklıkent}

Saklıkent Kayak Merkezi Akdeniz`e ve Ekvator`a en yakın kayak tesislerinden birisidir. Tesiste aralık - nisan ayları arasında yaklaşık 120 gün kaliteli kayak imkanı sunulmaktadır. Özellikle şubat sonu ve mart aylarında " Gündüz Kayak, öğleden sonra deniz" sloganı ile öne çıkan Saklıkent Kayak Merkezi, 1lıman iklimi sayesinde ülkemizdeki kayak merkezleri arasında sıcaklığın en yüksek olduğu kayak merkezidir. Güneşli gün sayısı sezon süresince 50-60 gün civarındadır. Saklıkent Kayak Merkezi'nde ortalama kar kalınlığı $100-200$ santimetre olup, zirvede bu kalınlık zaman zaman 4 metreye ulaşmaktadır. (http://www.saklikent.com.tr, 03.05.2018)

Saklıkent Kayak Merkezi, orman sınırlarının üzerinde konuşlanmasından dolayı, gerek kayağa yeni başlayanlar, gerekse profesyonel kayakçılar için oldukça uygun pistlere sahiptir. Kayak merkezinde 1 adet 1400 
metre uzunluğunda telesiyej, 2 adet teleski, 1 adet baby lift ve snowtubing lifti bulunmaktadır. (https://gezilmesigerekenyerler.com, 03.05.2018)

Kayak merkezinde konaklama tesisi ve telesiyej yap-işlet-devret modeli ile yapılmış olup özel sektör tarafından işletilmektedir. (http://www.ajansbir.com, 13.05.2018)

\subsubsection{Fenerbahçe Topuk Yaylası}

Düzce, Kaynaşlı İlçesi, Topuk Yaylası Mevkiinde 2011 Yılı Temmuz ayında açılan Fenerbahçe Serkan Acar Resort \& Sport Topuk Yaylası, yaklaşık 1300m rakımda, 150 dönümden büyük bir arazi üzerinde ve 2.500 metrekarelik bir alanda inşa edilmiştir. (http://www.fenerbahceturizmcatering.com, 21.07.2018)

Tesiste 3 adet UEFA standartlarına uygun çim futbol sahası, kış turizmi için kayak pisti, gece maçları için uygun aydınlatma sistemi, 400 kişi kapasiteli seyirci tribünü, $2 \mathrm{~km}$ göl çevresi yürüyüş yolu, orman içinde 4,5 $\mathrm{km}$. lik treking parkuru, piknik alanı, saha çevrelerinde tartan pist, standartlara uygun kapalı voleybol ve basketbol sahaları, 2 adet sauna, fin hamamı, Türk hamamı, Fitness merkezi, masaj, locanium-kapalı yüzme havuzu, göl kıyısında 1500 kişilik kokteyl alanı mevcuttur. Tesis, Fenerbahçe Spor Kulübü tarafından işletilmekte olup, Fenerbahçe Serkan Acar Resort \& Sport Topuk Yaylası Genel Müdürlüğü tarafından yönetilmektedir. (http://www.fenerbahceturizmcatering.com, 21.07.2018)

\subsubsection{Isparta Davraz}

Türkiye'de Akdeniz Bölgesi Göller Yöresi’nin doğal ve beşeri değerlerinden biri olan Davraz Dağı, Isparta şehir merkezine yakınlığı ve ulaşım olanakları yönünden turizm ve rekreasyon faaliyetleri için uygun ortam sunmaktadır. Günümüzde, kar kalitesi ve doğal güzellikleri ile kış turizmine hizmet eden Davraz dağında, 4094 hektarlık alan 17.02.1995 tarihli Bakanlar Kurulu kararıyla Kış Sporları Turizm Merkezi olarak ilân edilmiştir. Ayrıca çalışma alanı, topografik yapısının çeşitliliği, görsel peyzaj zenginliği ve spor faaliyetlerine uygun ortam sağlayan iklimi ile dikkate değer bir yapıya sahiptir. Eğirdir Gölü’nün güneybatısında bulunan Davraz Dağı, Isparta şehir merkezine $26 \mathrm{~km}$ uzaklıkta yer almaktadır. Toros Dağları'nın Batı Toroslar kesiminde $2635 \mathrm{~m}$. yüksekliği bulunan Davraz, kuzeyde Barla(Gelincik) dağları, doğuda Anamas dağları, güneydoğu da Kuyucak dağları, güneybatıda Akdağlar ile çevrilidir( Tokgözlü A., Temurçin K. VE Uysal K., 2012:60-61).

Isparta Ovasının doğusunda yer alan Davraz dağı, Batıda Isparta Ovasına, doğuda Kovada depresyonuna doğru kademeli bir şekilde alçalmaktadır. Kuzeybatıda Eğirdir gölüne doğru Yürlük dağı, batıda Küçük Davraz, güneydoğuda Asacak dağı gibi isimlerle adlandırılan Davraz dağının en yüksek noktası, $2635 \mathrm{~m}$ ile Ulparçukuru tepedir. Eğirdir gölünden Dereboğazı deresine kadar uzanan Davraz dağı üzerinde bulunan tepeler kayak potansiyelini destekleyen unsurlardandır. Bunlar; Kara tepe (2396 m), Çıkrıklı tepe (2013 m), Kocakır Tepe $(1675 \mathrm{~m})$ ve Garkın tepeleridir(1736 m). Davraz dağı ve çevresinin yükselti basamaklarına göre alan bakımından dağılımı incelendiğinde; 1200-1500 metreler arası \%33,1'lik bir oranla en fazla alanın bulunduğu basamağı oluşturmakta fakat bu alanda kış turizm faaliyeti yapılmamaktadır. Asıl faaliyetin yapıldığı, 15002000 metreler arasında kalan ve kayak pistinin de üzerinde bulunduğu saha \%31,7 ile kış turizminin yoğun olarak yapıldığı alana karşılık gelmektedir ( Tokgözlü A., Temurçin K. ve Uysal K., 2012:60-61).

Isparta ili, Akdeniz iklimi ile karasal iklim arasındaki geçiş bölgesinde yer almaktadır. Bu sebeple il sınırları içinde her iki iklim özellikleri de görülür. Isparta' da yarı kurak, az nemli, kışları serin, yazları sıcak bir iklim yaşanır. İlin Akdeniz'e yakın olan güney bölgelerinde Akdeniz iklimi özellikleri gözlenmektedir. Yazları sıcak ve kurak, kışları göre 1lık ve yağışlı geçer. Kuzeydoğuya gidildikçe karasal iklim özellikleri kendini gösterir. 
Kışlar daha soğuk geçer. Kuzey bölgeler daha az yağış alır (http://www.ispartakulturturizm.gov.tr, 10.05.2018).

Isparta Meteoroloji İstasyonu deniz seviyesinden 997 m yükseklikte kurulmuştur. Uzun yıllara ait (1975-2006) meteorolojik veriler değerlendirildiğinde; yıllık sıcaklık ortalamas $12{ }^{\circ} \mathrm{C}$ olduğu görülür. Bilindiği gibi kar örtüsünün uzun süre yerde kalması için sıcaklık değerlerinin $0{ }^{\circ} \mathrm{C}$ altında olması gerekir. Isparta' da yıllık ortalamalara bakıldığında, $0^{\circ} \mathrm{C}$ nin altında ölçülen gün sayısı yaklaşık 70 gündür. Ortalama sıcaklık değerleri incelendiğinde en yüksek ortalama sıcaklık değeri $23,5^{\circ} \mathrm{C}$ ile Temmuz ayında, en düşük sıcaklık değeri ise $1.8^{\circ} \mathrm{C}$ ile Ocak ayında görülür. Bu değerler yaklaşık $1000 \mathrm{~m}$ yükseklikte ölçülen değerlerdir. Isparta'dan 650 $1000 \mathrm{~m}$ yükseklikteki kayak merkezinde sıcaklık değerleri, Isparta'ya göre yaklaşık $3-5^{\circ} \mathrm{C}$ 'lik bir azalma gösterecektir. Isparta'da kar yağışlı gün sayısı yıllık ortalama 18,3 gün, karla örtülü gün sayısı ise 18,6 gün kadardır. Yılın 6 ayı kar yağışı geçmekte ve karın yerde kalma süresi daha uzun olmaktadır. Şüphesiz bu durum Davraz Dağı için daha uzun olacaktır. Nitekim Davraz Dağı kayak alanları ile Isparta kenti arasında ortalama 800 metre yükselti farkı vardır. Bu durum kayak merkezinde kar yağışları ve karın yerde kalma süresini uzatmaktadır. Kayak mevsimi süresince kar kalınlığ $50 \mathrm{~cm}$ ile 2,5 metre arasında değişmektedir. (Ceylan S., 2008:210-211)

Kayak merkezinde saatte 1000 kişiyi taşıyabilen 1211 metre uzunluğunda 1. telesiyej, saatte 800 kişiyi taşıyabilen 936 metre uzunluğunda 2. Telesiyej ve saatte 800 kişiyi taşıyabilen $850 \mathrm{~m}$ uzunluğunda 3. telesiyej olmak üzere 3 adet telesiyej, ayrıca saatte 800 kişiyi taşıyabilen 624 metre uzunluğunda bir adet teleski (T-Bar) ile 300'er metrelik 2 adet babylift bulunmaktadır. 1211 metre uzunluğundaki birinci telesiyej, iki kişilik iskemlelidir ve 1674 metrede yükseklikte başlayıp 1961 metre yükseklikte sona ermektedir. 936 metre uzunluğundaki ikinci telesiyej, iki kişilik iskemlelidir ve 1961 metre yükseklikte başlayıp, 2150 metre yükseklikte sona ermektedir. 850 metre uzunluğundaki üçüncü telesiyej ise, dört kişilik iskemlelidir ve 2080 metrede başlayıp, 2344 metrede sona ermektedir. Kayak Merkezinin 4. mekanik tesisi olan 624 metrelik T-Bar ile de, 1961 metreden 2150 metreye kayarak çıkılabilmektedir. Mekanik tesisler günde ortalama 4000 kişi taşımakta olup, Davraz Dağı-Karlıyayla Kış Sporları Turizm Merkezi İşletme ve Altyapı Hizmet Birliği tarafından işletilmektedir. (http://www.isparta.gov.tr, 20.05.2018)

Sirene Davras Oteli tekstil, turizm ve enerji alanında faaliyet yürüten Akkanat Holding bünyesinde yer almaktadır. Süleyman Demirel Üniversitesi Davraz Uygulama Oteli Eğirdir Meslek Yüksekokulu tarafından işletilmektedir. Tesis konaklama imkanının yanı sıra Üniversite bünyesinde yer alan Turizm ve Turizm İşletmeciliği bölümü öğrencilerine de staj ve uygulama olanağı sağlamaktadır. İsperia Davraz Otel'in mülkiyeti Isparta Valiliği Davraz Kayak Merkezi Altyapı Birliği'ne ait olup Tash Yatırım A.Ş. tarafından işletilmektedir. Davka Dağ Evleri Çobanisa Köyü’nde yerli girişimciler tarafından işletilmektedir. Mekanik tesisler günde ortalama 4.000 kişi taşımakta olup, Davraz Dağı-Karlıyayla Kış Sporları Turizm Merkezi İşletme ve Altyapı Hizmet Birliğince işletilmektedir(http://www.isparta.gov.tr, 20.05.2018).

\section{ARAŞTIRMA MATERYAL VE METOT}

Gerçekleştirilen araştırmada keşifsel araştırma modeli ${ }^{4}$ (ikincil kaynaklardan veri toplama ve konuyla ilgili deneyim sahibi kişilerin bilgisine başvurma) kullanılmıştır. Yapılan anket çalışması ile Davraz'da kurulması

${ }^{4}$ Keşifsel araştırmalar, bir araştırma problemi hakkında en genel düzeyde bilgi toplamak için yapılır. Bu araştırma türü,
araştırmacının çalıştı̆̆ konuyla ilgili mevcut bilgileri keşfetmesini sağlar ve daha sonra yapılacak olan daha detayl1
araştırmalar için zemin hazırlar. Araştırmacı, keşifsel araştırmayı tamamladıktan sonra araştırma konusuyla ilgili 
muhtemel yüksek irtifa kamp merkezinde nasıl bir tesis ve yönetim organizasyon yapısı oluşturulması gerektiği belirlenmeye çalışılmıştır. Çalışmada uygun örnekleme yöntemi kullanılmıştır. Sporcuların cinsiyet, yaş, eğitim, sporcu seviyesi ve demografik özelliklerine göre farklılaşma durumu incelenmiştir.

Araştırmada, Avusturya Mölltaler, Kayseri Erciyes ve Erzurum Palandöken Kayak Merkezlerinde yüz yüze anket yapılmıştır. Yapılan anketlere toplam 161 kişi katılmıştır.

Ankette yer alan sorular konu ile ilgili literatüre bağlı kalınarak hazırlanmıştır.

\section{BULGULAR}

Yurt içindeki ve yurt dışındaki yüksek irtifa kamp merkezlerinin yönetim-organizasyon yapıları incelendiğinde farklı yapılanmalar olduğu görülmektedir.

İsviçre St.Moritz Yüksek İrtifa Kamp Merkezi, St. Moritz Belediyesi tarafından kurulan sportif etkinlikler ve altyapı olmak üzere iki bölüme ayrılan St. Moritz Turizm departmanı tarafından işletilmektedir. Pazarlama faaliyetleri ise Engadin St. Moritz Turizm Organizasyonu tarafindan yürütülmektedir. St. Moritz Sportif Etkinlikler bölümü, St. Moritz'deki spor, etkinlik ve kültür programlarından sorumlu olup mevcut konukların memnuniyetini sağlamak, yeni konuklar çekmek ve irtifa eğitimi almak isteyen sporcular için akreditasyon sağlamakla görevlidir.

Kenya Iten'de yüksek irtifa kamp merkezleri girişimci sporcuların kurduğu şirketler tarafindan yönetilmektedir. Iten bölgesinde ve Kenyalı koşu topluluğunda yerel personel çalıştırılmakta olup, tüm çalışanlar Iten'de yaşamaktadır. Davraz, Iten'e göre emniyet açısından daha güvenli bir bölgededir.

4 kıtada 15'den fazla ülkede çalışmalarını sürdürmekte olan PGI Management Projesi (Türkiye - Erzurum, Grand Erzurum Kayak Merkezi İşletilmesi ve Yönetimi) Türkiye'nin en ünlü iki kayak merkezi olan Palandöken ve Konaklı tesislerinin yönetimini ve pazarlama faaliyetlerini yürütmektedir. PGI, tesislerin denetimi, işe alım süreci, satın alma listelerinin ve kayıt defterlerinin hazırlanması, bütçenin detaylandırılmasından sorumludur. Palandöken'de olimpiyatlar sırasında bir milli sporcu yeterli güvenlik önlemi alınmaması sebebiyle kaza geçirerek hayatını kaybetmiştir. Davraz Yüksek İrtifa Sportif Performans Analiz ve Kamp Merkezi'nde yer alacak tesisler tasarlanırken güvenlikle ilgili hususların iyi planlanması gerekmektedir.

Kayseri Palandöken Kayak Merkezi Kayseri Büyükşehir Belediyesi’nin yapmış olduğu yatırımları yönetmek üzere kurulmuş olan ve Türkiye'nin ilk ve tek dağ yönetim şirketi olan Kayseri Erciyes A.Ş. tarafından yönetilmektedir. Erciyes Dağı üzerinde bulunan teleferiklerin işletilmesi, kayak pistlerinin hazırlanması, güvenlik tedbirlerinin alınması, suni karlama sistemiyle kar üretilmesi gibi saha hizmetlerinin yanında yaz faaliyetleri ve sportif aktivitelerle alakalı bütün süreçler, Erciyes Kayak Merkezi'nin global çapta tanıtım ve pazarlanması, yurtiçi ve yurtdışı fuarlar, seminerler, sunumlar şirket tarafından yürütülmektedir.

Uludağ I. Gelişim ( Oteller ) Bölgesinde özel sektöre ait 18 adet turizm tesisi; kamuya ait 12 adet tesis, II. Gelişim Bölgesinde ise; özel sektöre ait 4 adet turizm tesisi hizmet vermektedir. Ayrıca Kirazliyayla'da kamuya ait 2 tesis bulunmaktadır. Oteller Bölgesinde kayak turizmine hizmet veren 22 adet mekanik tesis (teleskitelesiyej) mevcuttur. Teleski ve telesiyej hizmeti yap-işlet-devret modeli olarak Bursa Teleferik A.Ş. tarafından

topladığı bilgilere dayanarak araştırma problemini netleştirir. Keşifsel araştırmalar araştırmacının ilgilendiği konuyu en iyi hangi araştırma yöntemiyle inceleyebileceğine, hangi veri toplama araçlarını kullanacağına ve araştırmasına kimleri dahil edeceğine dair karar vermesine yardımcı olur. 
verilmektedir. Milli Parkta bulunan turizm ve kamu tesisleri daha çok kış turizmine yönelik hizmet vermektedir.

Saklıkent Kayak merkezinde konaklama tesisi ve telesiyej yap-işlet-devret modeli ile yapılmış olup özel sektör tarafından işletilmektedir.

Font Romeu, La Paz, Ilgaz ve Kartalkaya Spor Tesisleri'nin yönetim-organizasyon yapısı ile ilgili web kaynaklarından ve telefon yoluyla tarama yapılmış ancak bilgi alınamamıştır.

St Moritz'e en yakın havaalanı 201 km, Font Romeu'ya en yakın havaalanı 73 km, Iten'e en yakın havaalanı 36 km, La Paz'a en yakın havaalanı $5 \mathrm{~km}$, Palandöken'e en yakın havaalanı 13km, Erciyes'e en yakın havalimanı $13 \mathrm{~km}$, Ilgaz'a en yakın havaalanı $61 \mathrm{~km}$, Uludağ'a en yakın havaalanı $60 \mathrm{~km}$, Kartalkaya'ya en yakın havaalanı 200 km, Saklıkent'e en yakın havaalanı 87 km, Davraz'a en yakın havaalanı ise 36 km'dir. Bu verilere göre Davraz'ın havaalanına uzaklığı yurt dışından gelecek olan konuklar için ortalama bir mesafededir.

Uluslararası yüksek irtifa merkezlerinden St Moritz'de atletizm, koşu, yüzme, salon sporları, kürek, bisiklet, Font Romeu'da atletizm, yüzme, salon sporları, rugby, Iten'de atletizm, La Paz'da kayak, atletizm, bisiklet branşlarında antreman hizmetleri sunulurken, ulusal yüksek irtifa merkezlerimizde henüz kayak, trekking ve futbol ve kısmen bisiklet dışındaki branşlarda antreman hizmetleri bulunmamaktadır.

Avusturya Mölltaler, Kayseri Erciyes ve Erzurum Palandöken Kayak Merkezlerinde yapılan anketlere toplam 161 kişi katılmıştır. Ankete katılanların 71'inin milli sporcu, 52'sinin elit sporcu, 36'sının amatör sporcu ve 2 'sinin de ferdi sporcu olduğu sonucuna ulaşılmıştır.

Avusturya Mölltaler'da yapılan anketlere katılanların \% 46,7 si, Erzurum Palandöken'de ankete katılanların \% 26,6's1, Kayseri Erciyes'te ankete katılanların ise \% 34,8'i ulaşım hizmetlerinin pahalı olduğunu belirtmişlerdir. Davraz'da ulaşım hizmetinin ucuz verilmesine yönelik Kenya'da toplu taşıma hizmeti veren matatu isimli minibüslerin benzeri Davraz'a özgü taşıma sistemi tasarlanabilir.

Avusturya Mölltaler'da yapılan anketlere katılanların \% 76,7 si, Palandöken'de ankete katılanların \% 58,5'i, Kayseri Erciyes'te ankete katılanların ise \% 31'8'i dış alanların aydınlatmasının yeterli olduğunu belirtmiştir. Davraz Yüksek İrtifa Merkezi tasarlanırken gece dahi spor yapılabilecek düzeyde bir aydınlatma sisteminin kurulmasi gerekmektedir.

Avusturya Mölltaler' da yapılan anketlere katılanların \% 53,3'ü, Palandöken'de ankete katılanların \% 47,7'si, Kayseri Erciyes'te ankete katılanların ise \% 39,4'ü ise kayak merkezindeki tuvalet imkanlarından memnun olduğunu belirtmiştir. Kayak tesislerinde belirli aralıklarla tuvaletlerin konuşlandırılması ve temizliğinin düzenli olarak yapılması memnuniyeti artıracaktır.

Avusturya Mölltaler'da yapılan anketlere katılanların \% 76,7'si, Palandöken'de ankete katılanların \% 46,7'si, Kayseri Erciyes'te ankete katılanların ise \% 18,2'si açık alanlarda sunulan yiyecek-içecek ve takviye besinlerin yeterli olduğunu belirtmiştir. Sporcuların ve misafirlerin Davraz'da dış alanlardaki yiyecek içecek çeşitlerinin bol ve doyurucu olması tercih sebebi olacaktır.

Avusturya Mölltaler'da yapılan anketlere katılanların \% 10'u, Palandöken'de ankete katılanların \% 29,2'si, Kayseri Erciyes'te ankete katılanların ise \% 21,2'si sadece eğlenmek için tesislere geldiğini belirtmiştir. Bu sebeple kurulacak olan merkezde snowfest ve konser tarzı etkinlikleri fazla olması üstünlük sağlayacaktır. 
Tablo 1. Katılımcıların Mölltaler’a Eğlence Amaçlı Gelme Durumu

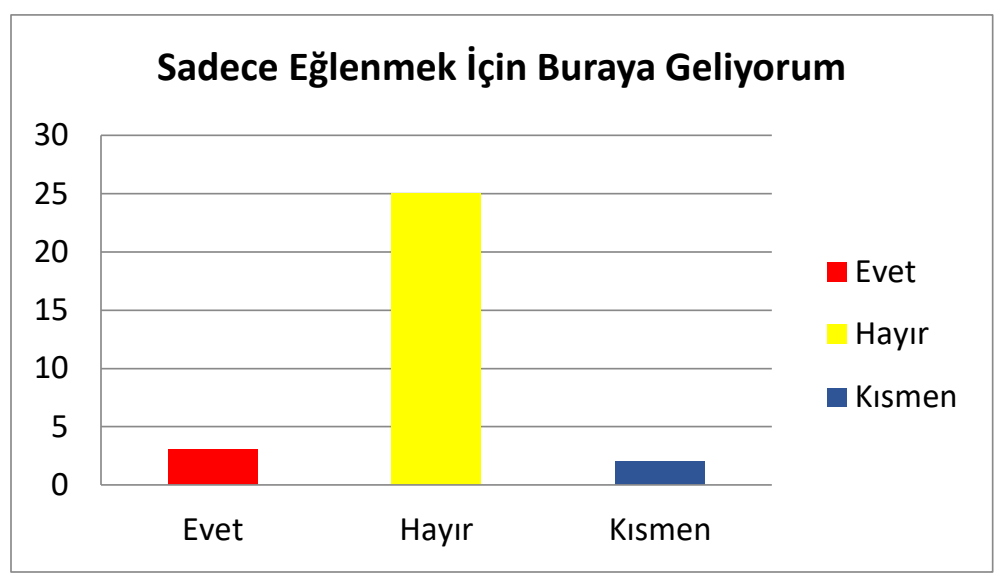

Tablo 2. Katılımeıların Palandöken'e Eğlence Amaçlı Gelme Durumu

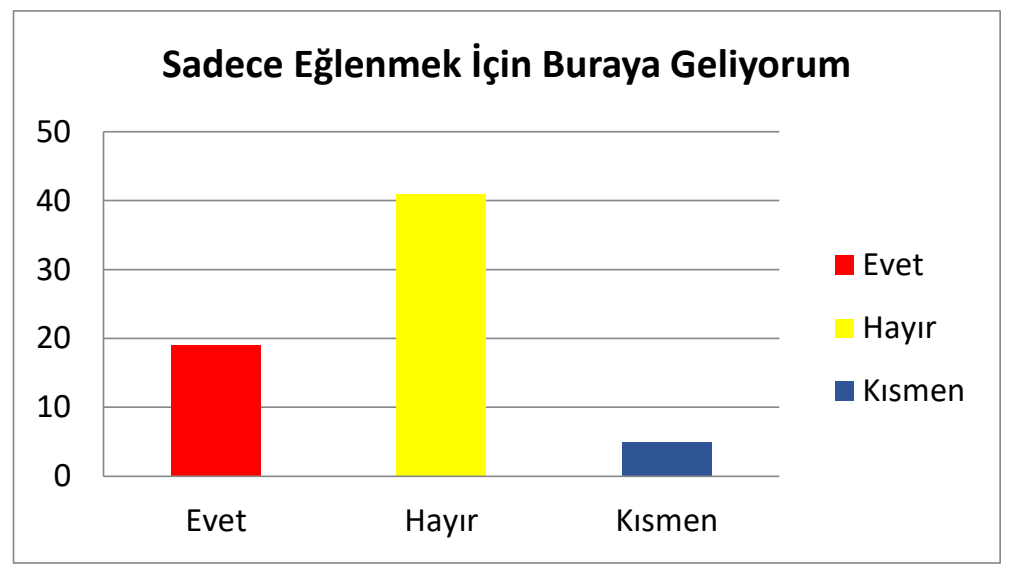

Tablo 3. Katılımcıların Erciyes'e Eğlence Amaçlı Gelme Durumu

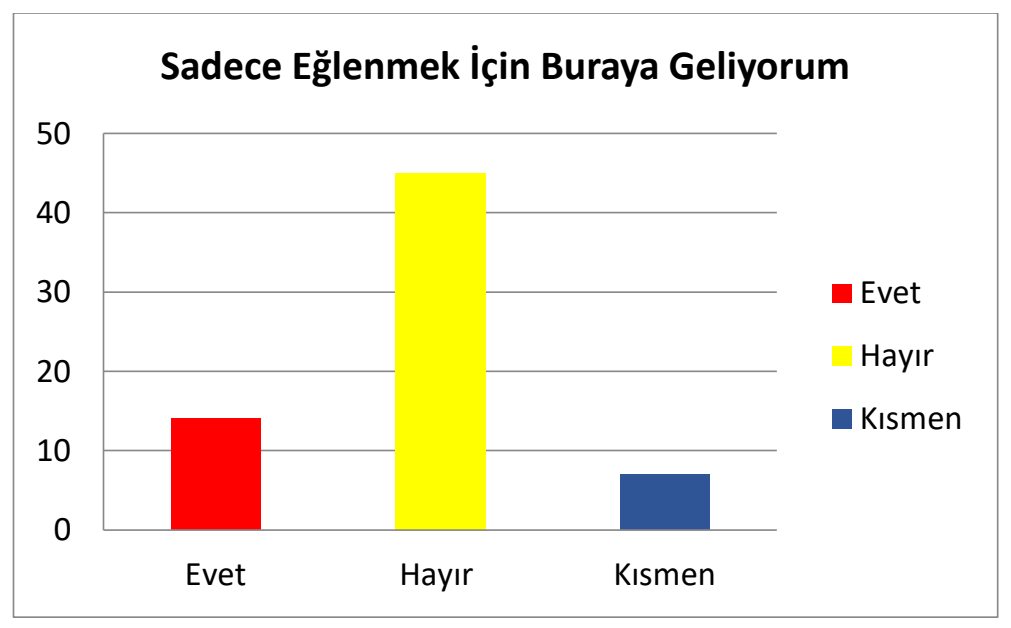


Isparta iklim koşullarının ve biyoklimatik konforunun uygunluğu, uygun yüksekliklerde son teknoloji ile yapılmış/yapılacak saha, salon, pist, havuz, test, antreman, beslenme, masaj ve sakatlık tedavisi gibi temel ihtiyaçların bütünsel olarak sağlayabilir spor tesisleri, gezilebilecek ve yaşanabilecek çok sayıda turistik değer ve etkinlikle çok çeşitli nedenlerle yüksek irtifa sporcu kampları için özellikle Nisan ve Ekim ayları arasında önemli bir cazibe merkezi olabilecek niteliktedir.

İstanbul veya Antalya'dan Davraz Kayak Merkezine 2-2,5 saat gibi kısa bir sürede ulaşılabilmektedir. Isparta'ya ve Davraz Dağı'na ulaşım kolaylığı bulunmasının yanı sıra trafik yoğunluğu, zaman kayıpları gibi stres faktörlerinin düşük olması büyük avantajdır.

Davraz Dağı'nın biyoiklimsel konfor düzeyi oldukça yüksektir. Akdeniz iklim özelliklerini göstermesinden dolayı kışları çok soğuk olmamakla beraber yaz aylarında $20 \mathrm{C}$ derece 1 sıyı geçmemektedir. Nem oranı \% 35 60 arasindadir.

Eğim antremanları sporcunun düz zeminlere oranla daha ağır dirençlere maruz kalmasına bağlı olarak performans gelişimini \% 50 artırmaktadır. Davraz Dağı hem yükselti hem de eğim antremanları için mükemmel bir konuma sahiptir. Oteller bölgesi 1650 m. yükseklik, \% 3,5-6 arası eğime, Sümbül Tepe 1965 m. yükseklik, \% 8-10 arası eğime, Masa Tepe 2087 m. yükseklik, \% 10-15 arası eğime, Oğlak Geçidi ise 2250 m. yükseklik, \% 15-20 eğime sahiptir.

Uluslararası yüksek irtifa merkezlerinin incelenmesi sonucu Davraz'a kurulacak olan yüksek irtifa merkezi tesislerinin kaliteli olması, tüm spor branşlarına cevap verebilecek nitelikte olması, saha, salon, pist, havuz, test, antrenman, beslenme, masaj, sakatlık tedavisi, güvenlik gibi temel ihtiyaçların bütünsel olarak karşılayabilir olması gerekmektedir.

\section{SONUÇ}

Uluslararası ve ulusal yüksek irtifa kamp merkezlerinin detaylı bir şekilde incelenmesi sonucu Süleyman Demirel Üniversitesi kampüs sahası içerisine konuşlandırılacak 15 bin seyirci kapasiteli stadyum, 2500- 5000 seyirci kapasiteli tenis kortları, Gölcük’te triatlon, duatlon, mtb, kamp ve müsabaka alanları, Davraz'da Yüksek İrtifa Sportif Performans Analiz ve Kamp Merkezi kurulması Isparta'nın spor turizminde atağa kalkmasını sağlayacağı düşünülmektedir. Davraz'da 1965 m rakımlı Sümbültepe'de 8900 metrekare alana kurulması planlanan Yüksek İrtifa Sportif Performans Analiz ve Kamp Merkezi'ne dünya standartlarında bir Performans Analiz Merkezi, kondisyon merkezi, oteller bölgesine antreman ve maçlar için 10 adet çim saha, spor hekimliği (önleyici ve tedavi merkezi), 1 adet takım spor salonu, 3 adet ferdi spor salonu, atletizm pisti, 50m. uzunluğunda 4 kulvarlı yüzme havuzunun inşa edilmesinin yeterli olacağı düşünülmektedir.

Isparta için turizm sektörünün eksikliklerinin en başında tanıtım yetersizliği gelmektedir. Turizm açısından pazarlamanın ve tanıtımının en iyi şekilde yapılabilmesi için, her yıl elde edilen turizm gelirlerinden kaynak ayrılması suretiyle etkin kullanılabilecek bir fon oluşturulmalıdır. Kenya örneğinde olduğu gibi tanıtım faaliyetlerinde dünya şampiyonu milli sporcularımız Hamza Yerlikaya, Taha Akgül gibi isimler reklam yüzü olarak kullanılmalıdır.

Bölgede spor turizminin gelişebilmesi için önem arz etmekte olan doğal ve kültürel değerler yönünden Isparta oldukça zengin bir şehirdir. Kamp merkezinden yararlanacak katılımcılar ve sporculara antremanların yorgunluğunu atabilmeleri amacıyla günü birlik Isparta'nın Değerleri Turu yaptırılması kent ekonomisine katkıda bulunulması açısından oldukça önemlidir. Isparta'nın Değerler Turu kapsamında Eğirdir Gölü ve Yeşil Ada, Gölcük Krater Gölü, Aksu Zindan Mağarası, Yalvaç Psidia Antiocheia Antik Şehri, Şarkikaraağaç Kızıldağ Kızılçam Ormanları, Yenişarbademli Pınargözü Mağarası, Uluborlu Kalesi ve Cirimbolu Su Kemeri, 
Uluborlu Kiraz Bahçeleri, Güneykent Gül Bahçeleri, Kuyucak Köyü Lavanta Bahçeleri, Gönen Yunus Emre Türbesi, Barla Bediüzzaman Said Nursi Evi, İslamköy Süleyman Demirel Külliyesi’ne gezi programları düzenlenmelidir.

Gönüllü Dopingle Mücadele Derneği (The Voluntary Anti-Doping Association VADA) tarafından kamp merkezinde temsilcilik açılması istenilmelidir. Bu ofis sayesinde kamp merkezinden yaralanacak sporcuları, katılımcıları, komisyonları ve kamuoyunu, performans artırıcı ilaç kullanma riskleri ile etkili beslenme ve eğitim uygulamalarından yararlanma konusunda eğitmek mümkün olacaktır.

Kurulacak olan yüksek irtifa kamp merkezinin diğer ülkelerdeki kamp merkezleriyle, özellikle komşu ülke Bulgaristan'da bulunan Belmeken Spor Kompleksi ile rekabet edebilmesi ve takımları çekebilmesi için fiyatları düşük, hizmet kalitesini yüksek tutulması gerekmektedir. Merkezde dünya standartlarında bir performans analiz merkezi, soğuk şok terapisi ve rejenerasyon sistemleri, üst düzey kondisyon salonları, cross fit salonları, Oteller bölgesinde çim saha, Sümbül Tepe ya da T Bar Bölgesine spor salonu (basketbol, voleybol, hentbol), taekwondo, güreş, jimnastik, karate, masa tenisi, badminton antremanlarında kullanılmak üzere 3 adet ferdi spor salonu, sporcuların her türlü sportif ve günlük ihtiyaçlarını karş1layabileceği bir süper market, kayak pistlerinde çeşitli noktalara tuvaletler inşaa edilmesi gerekmektedir.

Kamp Merkezinde pistler ve diğer tesislerde emniyet ve sağlık açısından uluslararası standartlarda koruyucu ve önleyici güvenlik tedbirleri alınmalıdır.

Kamp Merkezine ulaşım için Kenya'daki matatu benzeri yöreye özgü bir toplu taşıma aracı tasarlanması diğer yüksek irtifa kamp merkezlerinden ayırıcı bir özellik olacaktır.

Davraz Yüksek İrtifa Sportif Performans Analiz ve Kamp Merkezi’nin etkin bir şekilde kullanılabilmesi için sporun ve olimpik değerlerin her vatandaşın hayatının ayrılmaz bir parçası olduğu, kazanan bir olimpik ulus oluşturmak hedefiyle, ülkemizi uluslararası spor camiasında tanıtmak ve halkımıza olimpizm ruhunu aşılamak için faaliyet gösteren Türkiye Milli Olimpiyat Komitesi tarafından Türkiye Atletizm Federasyonu, Türkiye Kayak Federasyonu ve diğer branşlardaki federasyonlarla işbirliği içerisinde yönetilmesinin uygun olacağı düşünülmektedir. Ayrıca, yerel yönetim birimleri, Süleyman Demirel Üniversitesi, Isparta Uygulamalı Bilimler Üniversitesi yönetimlerinin merkeze sahip çıkarak destek vermesi beklenmektedir. 


\section{KAYNAKÇA}

Alışık A. (2010), Türkiye Dağları-Akarsu Havzalarına Göre, T.C. Alter Yayıncılık, Ankara, s. 150.

Bayer M.Z. (1992), “Turizme Giriş”, İstanbul Üniversitesi İşletme Fakültesi Yayınları, No:253, İstanbul.

Ceylan S.(2008), “Davraz Dağı(Isparta)’nda Kış Turizmi”, Eastern Geographical Review, s. 210-211.

Güzel N.A.ve Şenel Ç. (2001), "Yüksek İrtifada Yapılan Dayanıklılık Antremanlarının Kayak-Kros Sporcularının Bazı Performans Solunum ve Kan Parametreleri Üzerindeki Etkileri”, Gazi Beden Eğitimi ve Spor Bilimleri Dergisi, Cilt:6, Say1:4, s. 30-31.

http://erzurumdayatirim.kudaka.org.tr/?page_id=292 (09.08.2017)

http://hatc-iten.com/about (12.02.2018)

http://jdasolutions.aero/blog/lindberghs-hypoxia-research (09.08.2017)

http://www.ajansbir.com/haber-40887-40887-40887-Cennet_Kent_Saklikent_Kayak_Merkezi.html (13.05.2018)

http://www.bberzurumspor.com/tesisler (09.03.2018)

http://www.fenerbahceturizmcatering.com/isletmelerimiz/fenerbahce-resort-sport--topuk-yaylasi-

duzce_5.html (21.07.2018)

http://www.isparta.gov.tr/davraz-kayak-merkezi (20.05.2018)

http://www.ispartakulturturizm.gov.tr/TR,71025/iklim.html (10.05.2018)

http://www.kayserierciyes.com.tr/SkiResort/TravelPlaining?lng=1 (01.06.2018)

http://www.pgimgmt.com/tr/project/granderzurum-kayak-merkezi (08.05.2018)

http://www.runninginiten.com/training (20.02.2018)

http://www.saklikent.com.tr (03.05.2018)

http://www.tkf.org.tr/tr/kayak-merkezleri/palandoken/cografi-bilgiler (07.03.2018)

http://www.tkf.org.tr/tr/kayak-merkezleri/uludag/cografi-bilgiler (29.04.2018)

http://www.uludaginfo.com/uludag-tarih (29.04.2018)

http://www.whichtrainingcamp.com/sports/swimming-athletics-camp/font-romeu-france (05.01.2018)

http://www.whichtrainingcamp.com/sports/athletics-rowing-camp/st-moritz-switzerland (07.01.2018)

https://en.wikipedia.org/wiki/La_Paz (25.02.2018)https://gezilmesigerekenyerler.com/antalya/saklikentkayak-merkezi-nerede-ve-otel-bilgileri-antalya.html (03.05.2018)

https://gezilmesigerekenyerler.com/kayak-merkezleri/erciyes-kayak-merkezi-nerede-konaklama-ve-otelimkanlari-kayseri.html (06.04.2018)

https://kittbg.com/en/travel-bulgaria/sport/sport-complex-belmeken-velingrad (20.07.2018)

https://slovenianstravel.com/2015/11/07/estadio-hernando-siles-la-paz-high-altitude-football (25.02.2018) 
https://tr.ski-france.com/kayak-boelgesi-font-romeu/font-romeu (08.01.2018)

https://www.kulturportali.gov.tr/turkiye/kastamonu/turizmaktiviteleri/ilgaz-kis-sporlari-turzm-merkez (26.04.2018)

https://www.kulturportali.gov.tr/turkiye/bolu/gezilecekyer/kartalkaya-kayak-merkez (01.05.2018)

https://www.stmoritz.ch/en/service/about-us (13.02.2018)

Kozak N., Kozak M.A. ve Kozak M. (2012), “Genel Turizm İlkeler-Kavramlar”, Detay Yayıncılık, Ankara, s. 1.

Tokgözlü A., Temurçin K. ve Uysal K. (2012), "Winter tourism of Davraz Mountain”, Annales Universitatis Paedagogicae Cracoviensis, Studia Geographica III, s. 60-61.

Ülker İ.(1992), Dağ Turizmi-Planlama Yöntemleri-Yüksek Dağlarımız-Kayak Merkezleri, T.C. Turizm Bakanlığı, Ankara, s. 144-198. 